\title{
A VIDA BOA E O BEM VIVER: A UNIFICAÇÃO DOS PADRÕES ÉTICOS E MORAIS EM RONALD DWORKIN
}

\section{Lucas Sarmento Pimenta ${ }^{1}$}

\begin{abstract}
Resumo:
Pretendeu-se lançar luz sobre os conceitos de vida boa e de bem viver de Ronald Dworkin em sua obra "Justiça para Ouriços". Adotou-se o método dialético. Primeiro, expôs-se uma breve trajetória acadêmica do professor, para, depois, mostrar a sua visão sobre a ética, a moral e o direito inserido na moral. Descreveu-se a dignidade humana como elo entre estas duas, sendo o respeito próprio e a autenticidade seus princípios éticos fundantes. Ao final, concluiu-se que cabe a cada um, reconhecendo o valor do outro e a sua autenticidade, lutar por uma boa vida, fazendo-se jus à responsabilidade de viver.
\end{abstract}

Palavras-chave: Ronald Dworkin. Vida Boa. Bem Viver. Ética. Moral.

\section{THE GOOD LIFE AND LIVE WELL: THE UNIFICATION OF ETHICAL AND MORAL STANDARDS IN RONALD DWORKIN}

\begin{abstract}
:
The aim is to present Ronald Dworkin's concepts of good life and live well in his book "Justice for Hedgehogs". The adopted method was dialectic. First, a brief academic trajectory of the teacher was exposed, to later show his vision on ethics, morals and the law inserted in morals. Human dignity was described as a link between these two, with self-respect and authenticity as their founding ethical principles. It was concluded that it is up to each one, recognizing the value of the other and its authenticity, to fight for a good life, living up to the responsibility of living.
\end{abstract}

Keywords: Ronald Dworkin. Good Life. Live Well. Ethics. Morality.

\section{INTRODUÇÃO}

Ronald Myles Dworkin é reconhecido no meio acadêmico como um dos maiores filósofos do direito do final do século XX e início do século XXI. Sua maneira elegante e incisiva de se posicionar conquistou muitos apoiadores - cite-se Luís Roberto Barroso - e, principalmente, o respeito de seus opositores, como Jeremy Waldron (BARBOSA, 2013, p. 295).

\footnotetext{
${ }^{1}$ Mestrando em Teorias Jurídicas Contemporâneas pela Faculdade Nacional de Direito - FND/UFRJ. Graduado em Direito pela FND/UFRJ. Email: lucas_pimenta96@hotmail.com.
} 
Suas obras ultrapassaram os limites da Filosofia do Direito, invadindo os campos da Filosofia Moral e da Filosofia Política. Dessa forma, não é um autor lido apenas pelos estudantes de Direito, mas por todos aqueles que aceitam o convite do debate inteligente proposto por Dworkin.

Seus trabalhos versaram sobre as mais variadas temáticas. Sob pena de deixar muitas para trás, cita-se: liberdade religiosa, eutanásia, democracia, ética, moral, homossexualidade, ações afirmativas, aborto e, até mesmo, sobre o Movimentos dos Trabalhadores Sem Terra MST. Assim, firmou-se como um escritor que não tinha medo de expor suas ideias e de se lançar ao debate (BARBOSA, 2013, p. 290).

Ao longo de sua trajetória acadêmica, buscou dialogar, questionar e debater com teorias de outros estudiosos de relevância, como: Richard Rorty, Herbert Hart, Thomas Nagel, Isaiah Berlin, dentre outros. Nesse sentido, com elegância e coragem, Dworkin conquistou muitos defensores de suas ideias e, também, como não poderia de ser, um expressivo número de opositores (BARBOSA, 2013, p. 290).

Das muitas pérolas produzidas pelo filósofo norte-americano, será dado enfoque naquela que recebeu o instigante título de "Justice for Hedgehogs" - "Justiça para Ouriços", pouquíssimo explorada. A explicação para a escolha do nome e a interessante relação entre Dworkin e os ouriços será delineada na seção 1.

Este artigo tem como objetivo apresentar o olhar diferenciado e pouco conhecido que Dworkin tem pela Moral - e o Direito inserto nesta - e pela Ética, assim como a sua concepção de Vida Boa e de Viver Bem, explicada na obra supramencionada. Buscou-se mostrar a maneira inteligente como o autor une os dois conceitos por meio da dignidade humana, não abstrata, mas com parâmetros definidos por dois princípios éticos: respeito próprio e autenticidade.

A discussão se faz relevante por duas razões: a uma, porque, conquanto muitos trabalhos tenham Dworkin com referencial teórico, há uma escassez de artigos que discutam sua concepção de vida boa e de bem viver; e a duas, porque o entendimento destes conceitos poderá trazer desdobramentos benéficos às vidas individual e social dos indivíduos e, portanto, é - ou deveria ser - tema de interesse geral. 
A obra "Justiça para Ouriços" foi a última obra a ser publicada por Dworkin em vida $^{2}$. Ao ler as linhas de sabedoria do autor, logo percebe-se que não se trata de um livro comum, mas sim do auge de sua maturidade como escritor.

Consoante as penas de Flávio Quinaud Pedron e de José Emílio Medaur Ommati (2016, p. 244-245), Dworkin busca nessa obra "promover um esforço para integrar de maneira coerente seu projeto de filosofia moral e jurídica, recuperando discussões travadas ao longo de várias décadas".

Muito se conhece do filósofo americano a respeito da sua luta contra a discricionariedade dos juízes e do uso dos princípios para a solução dos hard cases. Para muito além desses termos, o trabalho de Dworkin ora sob análise chama a atenção para os conceitos de ética e de moral, sobre o que é ter uma vida boa e o que é viver bem. Nessa evolução, o jurista propõe uma releitura da teoria da unidade de valor, tese filosófica antiga, que será discutida mais à frente neste artigo.

O método utilizado nesta pesquisa foi o dialético, com abordagem qualitativa. Realizou-se pesquisa descritiva e exploratória, com procedimento bibliográfico, com enfoque maior nos textos produzidos por Ronald Dworkin.

Nos próximos itens, pretende-se, de início, dar uma visão perfunctória sobre a trajetória acadêmica de Ronald Dworkin até o lançamento da abra aqui discutida, para, ao depois, tratar especificamente da visão inovadora do autor sobre os institutos da Ética, da Moral e do Direito inserto nesta última. O núcleo do artigo tratará da possibilidade de sincronia entre padrões éticos e morais, por meio de uma releitura da teoria da unidade de valor.

\section{FILÓSOFO OURIÇO}

Antes do lançamento do livro "Justiça para Ouriços", a obra foi submetida à uma avaliação crítica e o autor incorporou boa parte das intervenções dos autores que compareceram ao debate na Universidade de Boston. Esse livro, portanto, é o produto de uma história (DWORKIN, 2012, p. 9-11).

\footnotetext{
${ }^{2}$ A obra "Religion Without God" - "Religião sem Deus" foi publicada em outubro de 2013, portanto, após a morte de Dworkin ocorrida em fevereiro daquele ano.
} 
Trata-se do último livro publicado pelo autor em vida. O autor começou a escrever em 1999, mas sua publicação só veio acontecer no ano de 2011. Isso porque esse livro foi construído dentro de um colóquio, liderado pelo professor Thomas Nagel, assim como por Dworkin, na Universidade de Nova Iorque, que se reunia uma vez por semana e em que os autores apresentavam os seus trabalhos ainda em desenvolvimento - "work in progress" - e os submetiam ao debate (MOTTA, 2013).

Essa atitude de diálogo de Dworkin foi uma verdadeira aula de como se trabalha em Filosofia do Direito. As teorias são postas em debate e dificilmente alguém tece comentários sobre alguma obra sem, antes, tê-la lido. Dessa maneira, nasce um trabalho rico em sabedoria e que, sobretudo, conversa e responde aos incômodos dos críticos.

Nesse momento, antes de se apresentar o percurso acadêmico do escritor até sua última obra publicada em vida, é importante fazer uma rápida digressão. Há cerca de quinze anos atrás, ainda não se estudava os trabalhos de Dworkin na graduação. Hoje, por outro lado, desde os primeiros períodos da faculdade - vide ementa de Filosofia Geral da Faculdade Nacional de Direito da Universidade Federal do Rio de Janeiro (2019) - os alunos já entram em contato com autores desta envergadura e outros que, da mesma maneira, os fazem, desde cedo, começar a raciocinar a respeito dos porquês do Direito e questionar aquilo que está posto.

Cabe, então, a pergunta: por que, hoje, tanto se fala e se estuda Ronald Dworkin? O que aconteceu para que esse autor se tornasse tão importante nos últimos tempos? A explicação, por óbvio, passa pelas transformações históricas que ocorreram nos últimos anos.

Em 1988, com uma clara mudança de regime, a nova Constituição colocou para as carreiras jurídicas desafios de interpretar princípios em uma constituição aberta; por exemplo, como é possível conciliar o direito à saúde universal com as limitações orçamentárias.

A partir daí, autores como Luís Roberto Barroso (2005) passaram a falar a respeito de Neoconstitucionalismo e de uma Nova Ordem Constitucional. Nesse contexto, autores como Ronald Dworkin e como Robert Alexy - que não faziam parte da biblioteca da maioria dos juristas brasileiros - começaram a ser utilizados como detentores das respostas que os novos desafios de interpretação do Direito traziam.

A Associação Brasileira de Filosofia do Direito e Sociologia do Direito, após o falecimento do autor em 2013, reconheceu, em seu sítio eletrônico, a sua influência marcante no Direito Constitucional brasileiro: 
Dworkin é certamente um dos mais influentes pensadores norte-americanos, e deixa órfãos vários filósofos e constitucionalistas brasileiros, que acompanhavam, de modo mais ou menos crítico, sua obra. Em especial o desenvolvimento do constitucionalismo no Brasil deve muito aos seus conceitos de Integridade e de Princípios Jurídicos (ASSOCIAÇÃO BRASILEIRA DE FILOSOFIA DO DIREITO E SOCIOLOGIA DO DIREITO, 2013). (grifo nosso)

Nesse sentido, grandes casos - hard cases - julgados no Supremo Tribunal Federal, como o uso de células tronco, o aborto de feto anencefálico e a união homoafetiva, não passaram pelas mãos dos ministros sem terem sido, antes, analisados sob a ótica da filosofia de Dworkin - vide voto do Ministro Luiz Fux reconhecendo a união estável entre pessoas do mesmo sexo (STF, 2011). A verdade, assim, para concluir esta digressão, é que este artigo é um reflexo dessa transformação jurídica ocorrida no país.

Uma boa maneira de relembrar a corrida acadêmica de Dworkin é iniciar pelo artigo “The Model of Rules” - “O Modelo das Regras" -, publicado em 1967, em que o autor retoma a diferenciação entre princípios e regras e expõe com clareza a sua crítica ao modelo do positivismo - principalmente aquele desenvolvido por H. L. A. Hart. Tem o autor, contudo, a honestidade de dizer que não sabe o que por no lugar do positivismo, que não tem uma solução, mas sabe, sem dúvidas, de que aquele sistema que estava não servia. Dez anos depois, este artigo foi incorporado à obra "Taking Rights Seriously" - "Levando os Direitos a Sério" (DWORKIN, 2002, p. XI).

Dworkin, com todo o seu poder de argumentação e sua elegância ao escrever, deu uma contribuição para a sofisticação do debate na Filosofia do Direito. Seus textos influenciaram - e ainda influenciam - autores no mundo inteiro. Em solo brasileiro, sua filosofia foi absorvida pelos juristas, a fim de justificar seus objetivos no contexto do país, o que fez com que, não raro, as teorias do filósofo fossem viradas de ponta-cabeça.

A noção de princípios e regras, por exemplo, apresentada pelo autor era uma ideia para limitar a discricionariedade judicial e nada além disso. No Brasil, contudo, essa ideia foi utilizada para servir de base aos defensores no neoconstitucionalismo e do pós-positivismo, que acreditam ter a Constituição força vinculante, mas também ter princípios que podem ser interpretados abertamente. Assim, os estudos de Dworkin, no dia a dia da Academia jurídicobrasileira, têm sido usados para outros fins que não os originais.

De volta ao pensamento original do filósofo, o professor mostra que os princípios seriam uma ponte que ligaria o Direito à Moral. Por isso, os princípios seriam utilizados para limitar a atuação dos juízes, limitar a sua discricionariedade. 
Quase vinte anos depois, em "Law’s Empire” - "O Império do Direito" - de 1986, Dworkin não retoma essa discussão entre princípios e regras, não utiliza isso como o argumento fundante da visão do Direito como integridade. $\mathrm{O}$ que se faz presente sim é uma ideia de ralação entre Direito e Moral, na ideia de moralidade política, na ideia do intérprete do Direito que, ao escrever a novela em cadeia, deve atender a moralidade política em que está atuando. O que qualificaria o bom intérprete do Direito e o tornaria apto à aplicação do Direito como integridade seria a compreensão da moralidade política na qual ele está inserido (DWORKIN, 1999, p. 275).

Percebe-se, então, que o filósofo norte-americano persiste na ideia da vinculação, da ligação estreita entre Moral e Direito, que o distingue, grosso modo, do positivismo. Ele mesmo diz que não é um antipositivista, mas um não positivista, pois não se trata de uma batalha contra o positivismo.

Dworkin estava numa busca de relação entre o Direito e a Moral, que superava em muito uma mera discussão antiga entre jusnaturalismo e juspositivismo. Dworkin, em " $\mathrm{O}$ Império do Direito", estava em uma busca por uma concepção do Direito que substituísse aquela que ele pensava não ser mais satisfatória. Dessa forma, apresenta o Direito como integridade.

Ainda no ano de 1986, seguindo a mesma lógica, em seu artigo "Freedom's Law: The Moral Reading of the American Constitution" - "Direito da Liberdade: A Leitura Moral da Constituição Norte-Americana" -, diz que a Constituição é escrita em termos muito abrangentes e que suscitam escolhas morais. Por exemplo, a liberdade de expressão seria a ideia moral de que é errado a interferência do Estado na forma ou no conteúdo da fala dos cidadãos. Desse modo, a sociedade, entendendo que esse preceito moral era muito importante, decidiu positivá-lo, tornando-se, assim, um direito (DWORKIN, 2006, p. 2).

Segundo Dworkin, o bom intérprete do Direito deve compreender essa relação entre Direito e Moral para aplicar a liberdade de expressão. Não haveria outra forma adequada para tal. O bom argumento e a boa interpretação pressupõem, de acordo com professor, que essa vinculação seja feita. Alguns críticos, como Kelsen (1996, p. 53) e seus discípulos, acreditam, porém, que isso seria entrar em um campo nebuloso demais e sem objetividade.

Finalmente - omitindo-se vários outros importantes trabalhos do autor nesse ínterim , chega-se em "Justiça para Ouriços". A utilização do termo "ouriço" foi inspirada em um dito do poeta grego Arquílogo, que diz que "a raposa sabe muitas coisas, mas o ouriço sabe uma 
coisa muito importante". Depois, em um famoso ensaio de Isaiah Berlin (1953, p. 3) sobre as obras de Tolstoi, aquele fez a classificação dos intelectuais segundo essa distinção entre raposas e ouriços. Diz assim Motta (2013) sobre essa questão:

\begin{abstract}
Aqui, a referência é feita a um trabalho de Isaiah Berlin, um filósofo moral que, num estudo sobre Tolstoi, faz uma comparação entre pensadores do tipo ouriços movidos por uma ideia central, que explicam a diversidade do mundo com referência a um único sistema - e pensadores do tipo raposas - que entendem que a diversidade do mundo, com seus fins vários e incompatíveis, não autoriza o uso de um único sistema explicativo. Berlin seria uma raposa; Dworkin, um ouriço. Ambos pegaram o mote de uma conhecida frase do filósofo grego Arquíloco, segundo quem "a raposa sabe muitas coisas, mas o ouriço sabe uma grande coisa". Para Dworkin, a tal grande coisa seria o valor. (grifo nosso)
\end{abstract}

Para ilustrar, pode-se citar alguns outros autores. Michel de Montaigne seria uma raposa, pois escreve sobre várias coisas diferentes em sua obra "Ensaios", sem uma ligação entre os assuntos. Aristóteles também entraria nesse grupo classificatório, pois fala da Ética à Nicômaco, mas também da política e da física. Platão, por sua vez, seria um ouriço, pois possui uma ideia unificadora que, em sua idealização das formas e percepção do que é permanente e do que não é, serviria como orientação de como interpretar e compreender o mundo - uma única ideia norteadora.

Em sua obra, Dworkin afirma querer ser um ouriço e foi exatamente isso o que fez. Não só em sua última obra, agora sob análise, mas em toda a sua história. Construiu uma grande matriz que o permitiu compreender e fazer as inter-relações entre o que é ser uma boa pessoa, o que é ter uma vida boa, o que é respeitar a liberdade e o que é viver em um mundo democrático. Teve uma ideia unificadora de tudo isso, uma vez que classificou-os como valores, ou melhor, uma rede de valores. Dworkin mostra, assim, que a verdade sobre os valores está em uma interpretação em rede; todos os critérios e valores articulam entre si.

Nessa cadência, a argumentação moral para o professor norte-americano seria uma argumentação interpretativa. Esta interpretação, contudo, deve seguir um princípio de responsabilidade (DWORKIN, 2012, p. 109-110). Não se pode tomar uma decisão, principalmente no que tange à vida política, que interfere na vida da comunidade, de qualquer maneira. As decisões devem ser tomadas de modo que, apesar da discordância, reconheça-se a integridade daquela posição. Dworkin se esforçou para assim se apresentar.

\title{
2 A ÉTICA E O BEM VIVER
}


Em “Justiça para Ouriços”, Dworkin (2012, p.197) dedica um considerável espaço Parte III - apenas para o estudo da Ética. Isso mostra como este assunto é caro ao desenvolvimento de todo o seu raciocínio que, como já foi demonstrado, segue o comportamento do ouriço de unidade. Dessa maneira, cabe uma análise minuciosa sobre como o escritor vai trabalhar com esse instituto.

O fato é que, como intelectual ouriço que é, Dworkin não traz agora uma teoria filosófica completamente nova. Na verdade, o que há é o aprofundamento de uma teoria que já estava presente em textos anteriores seus sobre moral, direito e ética. Faz-se essa ressalva, para que surja no leitor uma curiosidade de revisitar as obras passadas do autor para encontrar pressupostos da teoria agora apresentada.

Apesar do título desta parte do livro ser "Ética", o autor trata tanto da ética quanto da moral, já que, como será demonstrado na seção 4, propõe a unificação dos padrões éticos e morais.

Consoante o professor norte-americano, a ética teria a ver com as escolhas do indivíduo sobre a sua própria vida; seriam padrões que servem para orientar como o próprio indivíduo deve viver. É, portanto, um comportamento mais individual, focado na conduta do indivíduo, e não na coletividade como um todo.

Por outro lado, a moral seria um comportamento coletivo, seria o que este indivíduo deve aos outros. Os padrões morais, nessa esteira, serviriam para determinar como o indivíduo deve tratar as outras pessoas. Ou seja, um objetivo muito menos individualista do que a ética (DWORKIN, 2012, p. 199).

Vale ressaltar que os domínios desses termos - ética e moral - são muito controversos na história da filosofia. Nem todos os filósofos fazem a diferenciação trazida por Dworkin; o professor mesmo diz que alguns, ao revés, preferem usar moral e ética como sinônimos, eliminando a divisão por ele proposta (DWORKIN, 2012, p. 199). Assim, não se deve entender essa distinção entre os termos como algo pacificado na Academia.

O próprio Dworkin (2011, p. 607), em seu artigo intitulado “What is a Good Life?” "O que é uma Vida Boa?" - reconhece que a sua distinção entre os termos ética e moral é uma maneira especial de se estudar a matéria.

Muito embora haja muitas dissensões a respeito, o filósofo americano defende que a ética estaria relacionada com a busca da felicidade própria. A busca pela felicidade individual 
se confunde com que o autor entende por ética, aquilo que ele denomina como viver bem ou bem viver (DWORKIN, 2012, p. 199).

Logo no início do seu raciocínio, Dworkin (2012, p. 200) rechaça a possível pressuposição de que a ética seria direcionada a um individualismo egoísta. Ao contrário, ética e moral são interdependentes. Isto é, para que haja felicidade individual, é preciso que haja, também, uma boa relação com as outras pessoas da sociedade. Nesse sentido, ética e moral estariam completamente ligadas uma a outra, de modo que a primeira também está relacionada com o que se deve aos outros - a "vida boa" de Dworkin.

\begin{abstract}
Necessitamos de uma definição daquilo que devemos pensar que sejam nossos objetivos pessoais e que se adeque e justifique a nossa ideia de quais as obrigações, deveres e responsabilidades que temos para com os outros. Esta caracterização parece ajustar-se ao programa moral de Kant, pelo menos é isto que sugerirei mais à frente. A sua conceção da liberdade metafísica é mais esclarecedora quando entendida como um ideal ético que desempenha um papel dominante de justificação da sua teoria moral. O nosso próprio projeto interpretativo é menos fundamental por ser mais claramente holístico. Procuramos uma conceção do viver bem que possa guiar a nossa interpretação dos conceitos morais. Mas queremos, como parte do mesmo projeto, uma conceção da moral que guie também a nossa interpretação do viver bem (DWORKIN, 2012, p. 201) ${ }^{3}$. (grifo nosso)
\end{abstract}

Dworkin deixa claro que não basta só viver bem e não basta apenas ter uma boa vida. Assim, mesmo que, de fora, o indivíduo pareça ter uma boa vida, se ele não viver bem - for corrupto, por exemplo -, não terá uma vida boa de fato.

Ainda sobre a ética e o viver bem, o professor esclarece que bem viver é uma questão de responsabilidade. O autor dá atenção ao sentido de esforço. Os indivíduos precisam se esforçar para angariar bens. Não há uma preocupação com aqueles que levam uma vida mais irresponsável. A responsabilidade, para Dworkin, é um atributo individual muito importante. É o que se vê no seguinte trecho:

[...] Estamos incumbidos de viver bem devido ao simples facto de existirmos enquanto criaturas conscientes com vidas para viver [...] Temos a responsabilidade de viver bem, e a importância de viver bem faz parte do valor de ter uma vida fundamentalmente boa [...] A meu ver, uma pessoa que leve uma vida aborrecida e convencional, sem amigos íntimos, desafios ou realizações, só a fazer tempo até morrer, não tem uma vida boa, ainda que pense que é boa e que tenha apreciado a vida que teve. Se concordarmos, não podemos explicar por que razão se deve lamentar isto, chamando a atenção apenas para os prazeres perdidos; pode não ter havido prazeres perdidos e, de qualquer forma, nada há agora a perder. Devemos supor que terá falhado em alguma coisa: falhado na responsabilidade de viver (DWORKIN, 2012, p. 204). (grifo nosso)

\footnotetext{
${ }^{3}$ Note-se que todas as citações à obra "Justiça para Ouriços" estão em português de Portugal, razão pela qual algumas palavras podem parecer ter sito escritas equivocadamente.
} 
Ao fazer uma comparação entre a vida e a obra de arte, o escritor defende a valorização da vida bem vivida pelo desempenho apresentado no percurso, e não pela narrativa completa. É o que foi demonstrado neste excerto:

$\mathrm{O}$ valor de produto de alguma coisa é o valor que tem apenas como objeto, independentemente do processo pelo qual foi criado ou de qualquer outro aspecto da sua história. Uma pintura pode ter valor de produto, e este pode ser subjetivo ou objetivo. A sua organização formal pode ser bela, o que lhe dá o valor objetivo, e pode dar prazer aos espetadores e ser apreciado pelos colecionadores, propriedades que lhe dão o valor subjetivo. Uma réplica perfeitamente mecânica dessa pintura tem a mesma beleza. A questão de saber se tem o mesmo valor subjetivo depende, sobretudo, de se saber se se trata de uma réplica; para quem pensa que se trata do original, tem o mesmo grande valor subjetivo que esse original. No entanto, o original tem um tipo de valor objetivo que a réplica não pode ter: tem o valor de ter sido produzido através de um ato criativo com valor de desempenho. Foi criado por um artista com a intenção de criar a arte. O objeto - a obra de arte - é belo porque é o resultado de um desempenho belo; não seria belo se fosse uma réplica mecânica ou se tivesse sido criado por um acidente bizarro (DWORKIN, 2012, p. 205). (grifo nosso)

Nota-se que a arte se articula com a ideia de vida. Todos os indivíduos seriam autores dessa obra de arte que é a vida. Mais o valor maior não estaria no resultado final da vida, na narrativa final, mas sim na execução do bem viver, no esforço para se viver a vida. Assim, o indivíduo não precisa ser um grande autor, mas tem de se esforçar e dar o melhor de si na construção da obra.

[...] Quando uma pessoa faz bem qualquer coisa pequena - tocar uma melodia, representar um papel, jogar uma cartada, dar um toque na bola, fazer um elogio, fazer uma cadeira, um soneto ou amor -, a sua satisfação é completa em si mesma. São realizações da vida. Porque não pode uma vida ser também em si mesma uma realização completa, com o seu próprio valor na arte de viver (DWORKIN, 2012, p. 206)?

Por isso, Dworkin (2012, p. 205) diz que "o valor final das nossas vidas é adverbial e não adjetival". Ou seja, mais importa o esforço do atleta na sua preparação - a valorização da própria vida no dia a dia -, do que o resultado final da corrida - a narrativa final da vida.

A ideia é de que se o indivíduo se esforça, ou seja, não está dormindo, isso tem sentido e é valorado. É preciso romper com o estado de sonolência que o mundo propõe; isso é significativo. Vale mais o valor da execução do que o valor final do objeto. Com isso, o autor significa a obra e dá valor à ela pela seu esforço.

Consoante o filósofo norte-americano, tem sabedoria ética aquele que entende que é sua a responsabilidade de construir uma vida bem vivida. Para o autor, falta dignidade àqueles que procuram culpar os outros ou recorrem ao determinismo genético para tentarem se 
absolver de suas responsabilidades. A ideia de responsabilidade e de dignidade estão, aqui, de fato, interligadas. (DWORKIN, 2012, p. 218)

\title{
3 A MORAL E A VIDA BOA
}

Em “Justiça para Ouriços”, assim como em relação à ética, Dworkin dedica uma boa parte de sua obra desenvolvendo e uniformizando sua teoria moral. As discussões sobre o conceito de moral e de vida boa não passaram desapercebidas pelo autor. Dessa maneira, cabe uma análise cautelosa sobre como o escritor vai trabalhar com esse instituto e sua relação com o instituto anterior da ética.

Como já foi explicado alhures, Dworkin entende que a moral está ligada à forma como o indivíduo deve tratar os outros - diferente do padrão ético que busca a felicidade individual e o bem viver.

O filósofo refuta a noção comum de que as pressuposições morais são validadas de maneira subjetiva pelas crenças de determinada sociedade. Ao contrário, tem o entendimento de que existem verdades objetivas sobre o valor e de que a moral pode ser objetivada. Logo, seria possível falar em verdade e falsidade de pressuposições morais.

A concepção dworkiniana de se poder atribuir um juízo de veracidade aos valores muda completamente e confunde o sistema que estava posto. $\mathrm{O}$ autor assevera que, independentemente das crenças de determinado grupo social, algo pode estar objetivamente certo ou errado.

\begin{abstract}
Penso que algumas instituições são realmente injustas e que algumas ações são realmente erradas, independentemente de haver muita gente que acredite que não o são [...] Devo agora sintetizar aquilo que parece ser filosoficamente a ideia mais radical que defendo: a independência metafísica do valor. Trata-se da ideia familiar e absolutamente vulgar de que algumas ações - torturar bebés por divertimento são erradas em si próprias, e não só porque as pessoas as consideram erradas. Continuariam a ser erradas mesmo que, incrivelmente, ninguém assim as considerasse. Pode não acreditar nisso; alguma forma de subjetivismo moral pode parecer-lhe plausível. Mas o facto de ser verdadeira é uma questão de juízo moral e de argumentação (DWORKIN, 2012, p. 19-21).
\end{abstract}

É possível pensar em outros exemplos. Imagine-se que os nazistas tivessem ganhado a Segunda Guerra Mundial e, em todo o mundo, fosse legalizado o assassinato de todo aquele que se autodeclarasse judeu. $\mathrm{O}$ antissemitismo estaria correto nesse contexto? Dworkin dirá que não, pois matar judeus por preconceito é uma atitude errada, independentemente da crença social. 
Ora, não é preciso ficar restrito a exemplos internacionais. Até antes de 1888, quando da assinatura da Lei Áurea, a escravidão era algo comum na vida dos brasileiros. Alguns concordavam, outros discordavam. Contudo, seguindo os ensinamentos de Dworkin, independentemente do pensamento de cada cidadão brasileiro e de suas razões de defesa do sistema, a escravidão permanece sendo algo deplorável.

Esclarece o autor a sua proposta para a moral: "Proponho, então, uma compreensão diferente da ideia irresistível de que a moral é categórica. Não se pode justificar um princípio moral mostrando apenas que a obediência a esse princípio promove os desejos de alguém ou de toda a gente a curto ou longo prazo" (DWORKIN, 2012, p. 201).

Ou seja, a moralidade não é uma mera questão de opinião, mas de argumentação moral. Se algo é certo ou errado dentro de juízos de valor, isso dependerá do uso de argumentos morais, e não da simples apresentação de opiniões pessoais ou de crenças de determinadas sociedades.

Ainda, Dworkin dá um outro tom para o relacionamento entre Direito e Moral. Ele muda a relação do Direito com a Moral para dizer que o Direito é parte da moralidade. O Direito seria um ramo da moralidade em sentido amplo. Comparando à estrutura de uma árvore, o autor afirma que existiria um sub-ramo da moralidade política saindo do tronco da moralidade e que, desse sub-ramo, sairia o galho do Direito.

Os filósofos da política insistem num outro conflito entre valores políticos: o
conflito entre a justiça e o direito. Nada garante que nossas leis serão justas; se
forem injustas, os representantes do Estado e os cidadãos poderão ter de
comprometer as exigências da justiça para obedecer ao Estado de Direito. No
capítulo 19, refiro-me a esse conflito descrevo uma concepção de direito que não
o entende como um sistema rival de regras que podem conflitar com a moral,
mas sendo ele mesmo um ramo da moral (Dworkin, 2012, p. 17). (grifo nosso)

Assim, contrário ao velho - mas, resistente - paradigma de que Direito e Moral são sistemas normativos diferentes, Dworkin defende que o Direito se encontra circunscrito pela Moral. O Direito nada mais é, de acordo com o filósofo norte-americano, que uma pequena parte da resposta à questão desafiante, mas inevitável, sobre o que é viver bem e o que é ter uma boa vida.

Em “Justiça de Toga”, há uma reafirmação da aglutinação entre direito e moral:

Até o momento, minha argumentação não contestou a idéia tradicional de que 'moral' e 'direito' designam domínios de pensamento em princípio diferenciados, mesmo que talvez sejam interdependentes em diferentes sentidos. Afirmo agora que essa idéia tradicional, que nos estimula a estabelecer relações entre dois domínios intelectuais diferentes, é insatisfatória. Seria melhor atuar com uma topografia intelectual distinta: poderíamos tratar o direito como um segmento da moral, 
não como algo separado dela. Compreendemos a teoria política dessa maneira: como parte da moral compreendida em termos mais gerais, porém diferenciadas, com sua substância específica, uma vez que aplicável a estruturas institucionais diferenciadas. Poderíamos tratar a teoria jurídica como uma parte especial da moral política, caracterizada por um novo refinamento das estruturas institucionais (DWORKIN, 2010, p. 34-35). (grifo nosso)

Fica, assim, enterrada para o professor a ideia de que moral e direito são dimensões diferentes e que uma deve ser analisada separada da outra. Muito pelo contrário. O Direito é, em verdade, um ramo da Moral. Não haveria, portanto, nenhum direito que não pudesse ser justificado por argumentos morais.

\section{A SINCRONIA ENTRE OS PADRÕES ÉTICOS E MORAIS}

Em seu texto de maior maturidade, "Justiça para Ouriços", tema central deste artigo, Dworkin defende uma antiga tese filosófica: a unidade do valor. Diz assim Motta (2013) a respeito da versão dworkiniana da teoria da unidade do valor:

[...] no seu último livro, Justice for Hedgehogs (algo como Justiça aos Ouriços), somos apresentados a uma releitura de uma tese filosófica antiga, denominada de teoria da unidade do valor. Na versão dworkiniana, ela serve para subsidiar a afirmação de que as verdades sobre "o que é bom", sobre "como viver bem" ou sobre "como ser bom", são não só coerentes, mas também se apoiam reciprocamente. Haveria, assim, conformidade entre valores morais e éticos. Mais: haveria verdades objetivas (e não apenas subjetivas, pois) a respeito do valor. (grifo nosso)

Baseado em Platão e em Aristóteles, que entendiam ser a moral um gênero da interpretação, o professor destaca que a felicidade - já pensada como sinônimo de viver eticamente - só poderia ser alcançada por um indivíduo que respeitasse e seguisse os princípios da moralidade (DWORKIN, 2011, p. 607).

Contudo, como já foi explorado na seção anterior, o autor acredita na objetividade moral. Ou seja, não admite uma justificação moral apenas por crenças sociais ou naquilo que parece certo para alguém. No diálogo com o leitor do seu livro, chega, em tom de desabafo característico do filósofo -, a pensar no quão ruim seria se assim fosse:

Isso seria desapontador, porque precisamos encontrar autenticidade assim como integridade em nossa moralidade, e autenticidade requer que rompamos como nossas considerações manifestamente morais, para perguntar qual forma de integridade moral melhor se adéqua à decisão ética sobre como queremos conceber nossa personalidade e nossa vida (DWORKIN, 2011, p. 609).

Acontece que seria impossível fazer essa ligação entre moral e ética com uma ideia popular sobre o significado de bem viver. A ideia hobbesiana (HOBBES, 1988) de ética, por 
exemplo, de que o interesse próprio e a sobrevivência seriam os maiores bens precisa ser descartada. Faz-se necessário, então, ressignificar o conceito de viver bem.

Precisamos, então, de uma confirmação do que deveríamos considerar ser nossos objetivos pessoais, a qual se adéque e justifique nosso sentido de quais obrigações, deveres e responsabilidades temos para com outros. Procuramos uma concepção sobre viver bem que possa guiar nossa interpretação dos conceitos morais. Mas queremos como parte do mesmo projeto uma concepção da moralidade que possa guiar nossa interpretação sobre viver bem (DWORKIN, 2011, p. 610).

Como quis mostrar Dworkin no trecho acima, os interesses próprios deveriam ser criticados. Viver bem não é aquilo que a pessoa quer, mas aquilo que ela deveria querer.

Finalmente, Dworkin revela que o elo entre a moral e a ética seria a dignidade humana. Não uma noção vaga, mas operacional da dignidade. Para tanto, o autor apresenta dois princípios éticos que deveriam direcionar a dignidade e que seriam os requisitos fundamentais para se viver bem: o princípio do respeito próprio, em que cada um deve levar a sério a sua própria vida para não desperdiça-la; se esforçar e entender que a sua vida é importante por si só; e o princípio da autenticidade, em que, uma vez entendido o valor da vida, cada um deve seguir um modo de viver adequado à sua situação, e não pensando em agradar os outros (DWORKIN, 2012, p. 211).

Nessa esteira, devido à sua importância, toda vida deveria ser protegida, respeitada e, principalmente, levada a sério. E, uma vez não desperdiçada, a vida deve ser vivida de maneira autêntica, tendo cada indivíduo a responsabilidade de criar o seu próprio modo de viver, isto é, o seu estilo de vida.

Para ilustrar como se dá o convívio entre ética e moral, o filósofo nos convida à uma piscina com raias paralelas. Cada nadador deve se manter em sua raia. Entretanto, se outro nadador estiver se afogando, a mudança de raia é permitida para fins de ajuda. Mutatis mutandis, a ética seria o esforço de cada nadador para atingir o melhor desempenho em sua raia. A moral, por outro lado, seriam as raias e definiria em que circunstâncias a ultrapassagem poderia ocorrer. Dessa maneira, fica claro que a ideia dworkiniana de ética, de viver bem está em sincronia com aquilo que se deve fazer pelos outros, ou seja, com a moral (DWORKIN, 2012, p. 271).

Nessa concepção, a ideia popular de que políticos que enriqueceram ilicitamente levam uma vida boa estaria equivocada. Dado que fizeram dinheiro à custa dos outros - digase, imoralmente, romperam o elo da dignidade entre a moral e a ética. 
Segundo Dworkin, não é possível, uma vez que há uma unidade do valor, ter-se uma boa vida sem viver bem; um é complementar ao outro, visto que viver bem é a luta por ter uma vida boa.

Recorde-se que pretendemos integrar a ética na moral, não apenas pela incorporação da moral da ética, mas pela realização de uma integração mutuamente sustentadora das duas, na qual as nossas ideias sobre viver bem nos ajudem a perceber quais são as nossas responsabilidades morais (DWORKIN, 2012, p. 263) [...]

De outra mão, pode-se muito bem viver bem sem ter uma vida boa - o que o autor denomina de azar. Alguém que se esforçou para ter uma vida boa, mas foi acometido por uma doença grave ou morreu em um acidente não colherá aquilo que plantou. Por isso mesmo que Dworkin leciona que a luta é adverbial - isto é, importa mais o processo, e menos o resultado final da vida (DWORKIN, 2012, p. 427).

A verdade é que não há garantia alguma de que a vida será boa, mas pode-se, ou melhor, deve-se haver um empenho por parte do cidadão, para que ela seja bem vivida. Não basta ter preceitos éticos importantíssimos de educação, se não conseguir lidar com a comunidade ao seu redor. Ou seja, viver uma boa vida, ter responsabilidade e o respeito de si próprio como ser humano que importa, implica o convívio na pólis.

[...] Qual é, então, a responsabilidade ética mais fundamental? Viver bem. É eticamente irresponsável que uma pessoa viva menos bem a fim de tornar a vida melhor, e é inapropriado ter prazer ou orgulho no caráter bom da sua vida quando a pessoa conseguiu isso a custo de viver mal. Poderíamos dizer (usando um termo desenvolvido pelos economistas e que John Rawls popularizou entre os filósofos) que o valor de viver bem é lexicalmente anterior ao valor de uma vida boa. Contudo, o caráter bom de uma vida tem valor independente. Uma pessoa deve estar contente por ter uma vida boa, mas não se a conquistou à custa de enganos (DWORKIN, 2012, p. 209). (grifo nosso)

Percebe-se, portanto, que esta obra de Dworkin é uma espécie de tapeçaria, de costura, em que o autor busca, passo a passo, inter-relacionar todos esses valores de boa vida e de bem viver. Isso leva a uma ideia de unidade de valores.

\section{CONSIDERAÇÕES FINAIS}

Este artigo teve como condão apresentar o olhar diferenciado e pouco conhecido que Dworkin tem pela moral e pela ética, assim como a sua concepção de vida boa e de viver bem. Buscou-se mostrar a maneira inteligente como o autor une os dois conceitos por meio da dignidade humana, não abstrata, mas com parâmetros definidos pelos dois princípios éticos: respeito próprio e autenticidade. 
Sua teoria ética consiste em levar a vida a sério, valorizá-la e reconhecer a sua importância, onde o bem viver surge nessa luta por valorização, ou não desperdício, da vida. Sua teoria moral, por sua vez, preconiza que cada um, já sabendo da importância de sua própria vida, trate os demais reconhecendo-lhes o seu alto valor. A dignidade, por derradeiro, vincula a moral à ética, por meio do reconhecimento da igual importância do outro e do respeito à autenticidade de cada um.

Ao longo desta exposição, restou claro que o filósofo norte-americano defende o seu sistema de pensamento a partir de um princípio fundamental: a unidade e interdependência dos valores éticos e morais, sendo a dignidade humana o elo que liga os dois últimos. Por isso, não se deixou de mencionar a crítica incisiva do autor contra a ideia de que viver bem é fazer aquilo que bem entender.

Assim, após esta breve explicação, cabe a cada um refletir, de maneira autêntica, acerca de como tem trilhado o caminho da vida, tendo a certeza de que não há um modo padronizado de viver bem e de se alcançar uma vida boa. Há sim - e que disso não se duvide jamais - muitas maneiras de se esforçar e de se fazer jus à responsabilidade de viver, sem, contudo, passar por cima de ninguém para tal. Como Dworkin (2012, p. 25) mesmo diz:

Temos de encontrar o valor de viver - o sentido da vida - no viver bem, tal como encontramos valor em amar, pintar, escrever, cantar ou mergulhar bem. Não há outro valor ou sentido duradouro nas nossas vidas, mas são valores e sentidos suficientes. De facto, é maravilhoso.

Registre-se, aqui, em termos finais, o respeito deste articulista pela humildade de Ronald Dworkin em vida. Antes do livro ser publicado, é bom ser ressaltado, houve cerca de trinta artigos criticando, em simpósio aberto pelo próprio filósofo, aquilo que seria dito pelo autor (DWORKIN, 2012, p. 10). Com isso, Dworkin demonstrou não só responsabilidade científica, mas também que seus ensinamentos ultrapassavam as páginas de seus livros.

Deve-se, por último, admirar a caminhada do autor e a sua jornada percorrida com excelência. Há, de fato - e houve uma tentativa para se mostrar isso neste artigo -, um esforço de coerência e de integridade em seus escritos ao longo de toda a sua vida, o que faz com que seja coerente o seu auto-reconhecimento como um filósofo ouriço.

\section{REFERÊNCIAS}


ASSOCIAÇÃO BRASILEIRA DE FILOSOFIA DO DIREITO E SOCIOLOGIA DO DIREITO. Morre Ronald Dworkin. 2013. Disponível em: $<$ http://filosofiadodireito.org. $\mathrm{Br} / \mathrm{site} /$ ?p=230>. Acesso em: 21 jul. 2019.

BARBOSA, Leonardo Figueiredo. Ronald Dworkin: uma homenagem a um filósofo porcoespinho. Revista Direito e Práxis. Vol. 4, n. 7, 2013.

BARROSO. Luís Roberto. Neoconstitucionalismo e constitucionalização do Direito: O triunfo tardio do Direito Constitucional no Brasil. Revista de Direito Administrativo, v. 240, Rio de Janeiro: FGV, 2005.

BERLIN, Isaiah. The Hedgehog and the Fox: An Essay on Tolstoy's View of History. Londres: Weidenfeld and Nicolson, 1953.

DWORKIN, Ronald. Direito da Liberdade: A Leitura Moral da Constituição NorteAmericana. São Paulo: Martins Fonstes, 2006

Justiça de Toga. São Paulo: Martins Fontes, 2010.

Justiça para Ouriços. $1^{\circ}$ ed. Coimbra: Almedina, 2012.

Levando os Direitos a Sério. São Paulo: Martins Fontes, 2002.

. O Império do Direito. São Paulo: Martins Fontes, 1999.

O que é uma vida boa? Revista Direito GV. Trad. Emilio Peluso Neder Mayer e Alonso Reis Freire. no 14. Jul/Dez 2011.

HOBBES, Thomas. Leviatã, ou, Matéria, forma e poder de um estado eclesiástico e civil. Tradução de João Paulo Monteiro e Maria Beatriz Nizza da Silva. 4 ed. São Paulo: Nova Cultural, 1988.

KELSEN, Hans. Teoria Pura do Direito. Tradução de João Batista Machado. 5. ed. São Paulo: Martins Fontes, 1996.

MOTTA, Francisco José Borges. Ronald Dworkin e o sentido da vida. Revista Consultor Jurídico, 16 de fevereiro de 2013. Disponível em: https://www.conjur.com.br/2013-fev16/diario-classe-ronald-dworkin- sentido-vida. Acesso em 21 jul. 2019.

PEDRON, Flávio Quinaud; OMMATI, José Emílio Medaur. De que maneira a Administração Pública se vincula ao Princípio da Dignidade da Pessoa Humana? A resposta de um "ouriço" sob os pressupostos do pensamento de Ronald Dworkin. In: Ronald Dworkin e o Direito Brasileiro. José Emílio Medaur Ommati (Coord). V. 2. Rio de Janeiro: Lumen Juris, 2016, p. 244-245.

STF. AÇÃO DIRETA DE INCONSTITUCIONALIDADE: ADI 4277 DF. Relator: Ministro Ayres Britto. DJ: 05/05/2011. JusBrasil, 2009 Disponível em: https://stf.jusbrasil.com.br/ 
jurisprudencia/20627236/acao-direta-de-inconstitucionalidade-adi-4277-df-stf. Acesso em 21 jul. 2019.

UNIVERSIDADE FEDERAL DO RIO DE JANEIRO. Ementa de Filosofia Geral. Disponível em: https://www.siga.ufrj.br/sira/temas/zire/frameConsultas.jsp? mainPage=/repos itorio-curriculo/9F2250E6-92A4-F79C-26F7-1E7427330D4D.html Acesso em: 21 jul. 2019. 